\title{
A Systematic Review and Meta-analysis of Diagnostic Accuracy of Serum (1- 3)-Beta-D-glucan for Pneumocystis Jirovecii Pneumonia Using the Fungitell Assay: Focus on Cutoff Levels
}

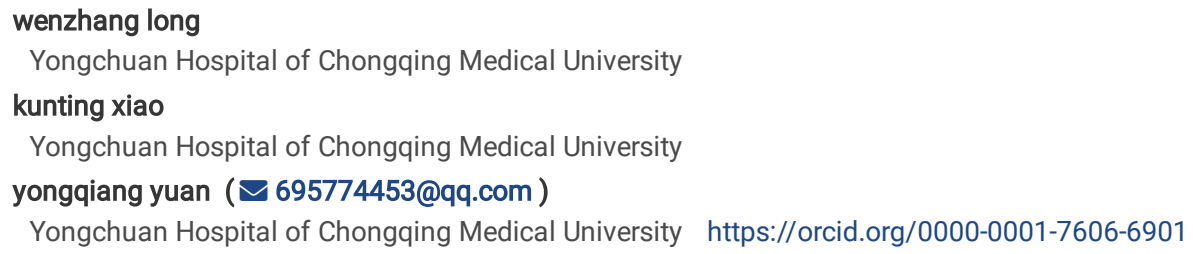

\section{Research Article}

Keywords: (1,3)-Beta-D-glucan (BDG), Pneumocystis jirovecii pneumonia (PJP), sensitivity and specificity, positive likelihood ratio(LR+), negative likelihood ratio (LR-), meta-analysis

Posted Date: July 16th, 2021

DOI: https://doi.org/10.21203/rs.3.rs-708757/v1

License: () (7) This work is licensed under a Creative Commons Attribution 4.0 International License. Read Full License 


\section{Abstract}

Purpose

We conducted a meta-analysis to evaluate the diagnostic performance of various levels of serum (1-3)-Beta-D-glucan(BDG) for Pneumocystis jirovecii(PJ) infection using Fungitell assay.

Methods

EMBASE, MEDLINE, and the reference lists of relevant studies were identified up to March 12,2021, with no language restrictions. Meta-analysis was performed using random-effects models for bivariate analysis. Subgroup analyses were implemented in HIV-positive Pneumocystis jirovecii pneumonia (PJP), HIV-negative PJP, and PJP versus colonized patients.

Results

Nineteen individual studies that included a total of 2,310 participants met our inclusion criteria. The overall sensitivity, specificity, positive likelihood ratio(LR+) and negative likelihood ratio (LR-),and 95 \% confidence interval Cl of serum-BDG were 0.94(95 \% Cl: 0.89-0.96),0.76 (95\% Cl: 0.65-0.85), 3.99 (95\% Cl: $2.59-6.13), 0.08$ (95\% Cl: 0.05-0.15), respectively. Futher stratified analysis of diagnostic values showed that various levels of serum BDG differed in sensitivity, specificity, LR+ and LR- in the diagnosis of PJP. Subgroup analyses also indicated that the cutoff value of $200 \mathrm{pg} / \mathrm{mL}$ had sufficient diagnostic accuracy in HIV-positive PJP patients versus controls. Moreover, the $80 \mathrm{pg} / \mathrm{mL}$ cutoff value had satisfactory diagnostic accuracy in PJP versus colonized patients, a overall sensitivity of $0.86(95 \% \mathrm{Cl}, 0.73-0.93)$, a overall specificity of $0.82(95 \% \mathrm{Cl}, 0.73-0.88)$, a overall LR+ $4.70(95 \% \mathrm{Cl}: 3.11-7.08)$, and a overall LR-0.17(95\% Cl: 0.09-0.34),individually.

Conclusions

This meta-analysis suggests that the optimal positive threshold for serum BDG, tested by the Fungitell assay, requires better definition and clinical validation rather than the recommended cutoff of $80 \mathrm{pg} / \mathrm{mL}$ by the manufacturer in the diagnosis of PJP. These cutoff values could be further refined in additional studies that focus on populations that are as homogeneous as possible.

\section{Introduction}

Pneumocystis jirovecii(PJ) is a life-threatening opportunistic pathogen that causes Pneumocystis jirovecii pneumonia (PJP) in the respiratory system. PJP mainly occurs in patients with acquired immunodeficiency syndrome (AIDS), malignant tumor, autoimmune disease and other immunocompromised. The main clinical symptoms and signs usually include exertional dyspnea, dry cough, and subfebrile temperature or fever, which are atypical, rapid progress, high mortality [1-4].

At present, PJ can not be grown in culture in the clinical laboratory. Microscopic staining in sputum and bronchoalveolar lavage (BAL) samples has been the gold standard for diagnosis for decades [5-6].However, the limited sensitivity of the test, range from 50 to $90 \%$ [7-8],which depending on technique proficiency and the experience of the laboratory,and that may result in delayed diagnosis of PJP. Previous studies have shown that PJ-PCR have a high success rate PJP diagnosis in HIV-positive and -negative individuals [9]. Nevertheless, this technique is defective because of its high false positive rate, which may lead to asymptomatic colonization or subclinical infection in patients with positive results [10-12]. While most of those studies examined BAL fluid specimens, and since BAL is an invasive method that can not be used to PJP seriously ill patients and infants, which are associated with increased risk of respiratory failure, an accurate, non-invasive method is needed.

PJP classically presents with interstitial opacities on chest X-ray and computed tomography (CT) [13]. Previous study has found that the chest radiographic findings may be normal in patients with early mild disease, although under exertion heart rate and oxygenation levels may become abnormal [14]. While CT has high sensitivity for PJP in patients with HIV infection [15], only negative (normal or unchanged) CT scan findings do not rule out PJP.

(1-3)-B-D-Glucan (BDG) is a common cell wall constituent of most pathogenic fungi, including PJ. The use of assays to detect BDG is now widely accepted and allows the detection of readily available serum specimens. To our knowledge, there are at least three BDG assays available commercially: the Fungitell assay (Associates of Cape Cod), the Wako BDG assay (Fujifilm Wako Pure Chemical Corporation, Ltd., Osaka, Japan), and the Fungitec-G tests (Seikagaku, Kogyo, Tokyo, Japan). Among them, only Fungitell trials were FDA approved (in 2004) and CE marked (in 2008). The other two tests have been used in routine diagnostics in Japan for 20 years, without FDA approval and CE marks, thus limiting their application in routine diagnostics in other countries [19]. However, the effectiveness of the Fungitell assay or, if used,which is better cutoff level for PJP screening has not been established. To date, there is a lack of clinical trials for serum BDG performance of diagnostic PJP [16-17]. In fact, different levels of serum BDG have been associated with a high sensitivity or specificity for the diagnosis of PJP individuals [18]. In addition, there was partial heterogeneity due to the threshold effect in a former meta-analysis study [53]. Because of those, the aim of the present study was to evaluate the diagnostic accuracy of PJP at different cut-off levels of serum BDG tested by Fungitell assay, and translation of these studies to clinical applications.

\section{Methods}

Literature search

Electronic literature retrieval was carried out using MEDLINE(from 1950 to March 12,2021) and EMBASE(from 1974 to March 12,2021). There are no language restrictions. Study keywords were 1) text or subheading words registered in MEDLINE or EMBASE related to PJP, BDG, and PJ-PCR; and 2) text words related to 
diagnostic values that evaluated the use of serum BDG for PJP diagnosis.Details of the search strategy was: 1) MEDLINE search: ("pneumocystis pneumonia" OR "pneumocystis carinii pneumonia" OR"pneumonia, pneumocystis carinii" OR "pneumocystis jirovecii pneumonia" OR

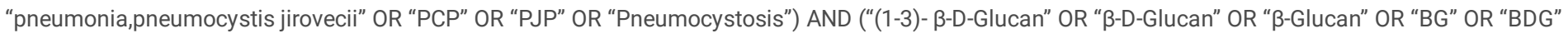
);and 2) EMBASE search: 1\#'pneumocystis pneumonia' OR 'pneumocystis pneumonia' OR 'pneumocystis jirovecii pneumonia' OR 'pneumocystis jirovecii pneumonia' OR 'pneumonia,pneumocystis jirovecii' OR 'pcp' OR 'pjp' OR 'pneumocystosis' OR 'pneumocystosis';2\#'1-3- $\beta$-d-glucan' OR ' $\beta$-d-glucan' OR ' $\beta$-glucan' OR 'bg' OR 'bdg';3\#1\# AND 2\#.We did not include abstracts or meeting's proceedings. Results were arbitrated by a third investigator (Y. Yuan). We additionally searched in the reference lists of relevant articles to identify eligible for inclusion studies.

Study selection

Inclusion criteria were: 1) cross-sectional study for assessing the diagnostic value or cohort study for assessing the predictive value; 2) PJ infections were defined as either definite, probable, possible, or not PJP, as described for other invasive fungal diseases,with some modifications (Table 1) [20-21], and the definite and probable patients were our target population , namely PJP patients; 3) serum BDG measured by the Fungitell assay in all subjects and used recommended or different cutoff values than in current PJP criteria as an index test; 4) used the same reference standard for all participants to avoid differential verification; and 5) allowed reproduction of the diagnostic or predictive $2 \times 2$ contingency table (i.e., number of true-positive, false-negative, truenegative, and false-positive cases) for BDG tests. Disagreements were discussed among the group until a consensus was reached.

Data extraction

From each study two investigators (W. Long and K. Xiao) independently extracted the following information: first author, publication year, BDG cutoff level, geographical region,language, mean or median age of subjects,population characteristics, study design, prophylactic antifungal therapy, HIV status of patient population and diagnostic data for two-by-two tables using a standardized protocol and reporting document to ensure consistency. If the criteria for the diagnosis of PJP were not directly provided, the article would be excluded in the present study. When analyzing the same population in several publications, the results were calculated only once. When evaluating HIV-related and -unrelated PJP patients in the same report, we emailed authors for further information and extracted data separately if available.

Study quality was performed using the Quality Assessment of Diagnostic Accuracy Studies 2 score (QUADAS-2) tool [23], which is a quality assessment tool comprised of 4 domains: patient selection, index test, reference standard, and flow and timing. The risk of bias is assessed in each of the domains by indicating a 'low', 'high' or'unclear' rating. Of the 4 domains, the following 10 items were focused on as being most relevant for our purpose[23]. Domain 1 (Patient Selection): 1) Was a consecutive or random sample of patients enrolled? 2) Was a case-control design avoided? 3)Did the study avoid inappropriate exclusions?; Domain 2 (Index Test): 4) Were the index test results interpreted without knowledge of the results of the reference standard? 5) If a threshold was used, as it presignified? ; Domain 3 (Reference Standard): 6) Is the reference standard likely to correctly classify the target condition?; 7) were the reference standard results interpreted without knowledge of the results of the index test?; Domain 4 (Flow and Timing):8) Was there an appropriate interval between the index test and reference standard?; 9)Did all patients receive the same reference standard?; 10) Were all patients included in the analysis?

Data synthesis

We carried out a meta-analysis of the point estimate of sensitivity, specificity, LR+ calculated as sensitivity/(1-specificity) , LR- calculated as (1sensitivity)/specificity, and diagnostic odds ratios (DOR) calculated as sensitivity/(1-specificity) ×specificity /(1-sensitivity) and their corresponding $95 \%$ Cl by using a bivariate random-effects. On the other hand, we constructed a hierarchical summary receiver operating characteristics (HSROC) curve by using the two independent parameters that have normal distribution (accuracy, cutoff point) and scale parameters that allow asymmetry of the ROC curve [24]. Both models show different aspects of ROC data, but both are very closely related and are usually the same [25].

LR+ and LR- values would be used to assess diagnostic or predictive ability in PJP screening. We judged results with $L R+>10,5$ to $\leq 10,2$ to $\leq 5$, and $<2$ as providing conclusive, strong, weak, and negligible evidence, respectively, for confirming PJP (i.e.,diagnosing or predicting PJP with a high level of confidence). And results with LR- $\leq 0.1,0.1$ to $\leq 0.2,0.2$ to $<0.5$, and $\geq 0.5$ were judged as giving conclusive, strong, weak, and negligible evidence, respectively, for excluding PJP (i.e., confirming that a person does not or will not develop PJP) [51].

The results for heterogeneity were assessed by calculating a $Q$ statistic, which we compared with a $\chi^{2}$ distribution, and the I-squared index [26]. The $Q$ test shows the statistical significance of homogeneity hypothesis and the $\mathrm{I}^{2}$ index measures the degree of heterogeneity. The results of heterogeneity would be considered to be significant at $\mathrm{P}<0.10$ (both sided). Publication bias was ascertained by visually examining for funnel plot asymmetry and quantified by using the Egger's test to calculate two tailed $P$ values [27].

\section{Results}

Literature search

In total, 439 citations were identified by the electronic search, after excluding studies for relevant reasons, a total of 19 studies [32-50] were included in this meta-analysis. Details of the literature search for obtaining these articles are shown in Figure 1. Of the 19 studies, 16 studies [32-34,37-39, 41-50] were casecontrol studies, 1 study [40] was retrospective studies, and 2 studies [35-36] were cohort studies. Two studies [44,47] investigated various cutoff values of serum BDG in definite, probable, possible/colonized patients and controls, respectively. Three studies [40,42,50] investigated the various cutoff values of serum BDG in definite/probable, possible/colonized patients and controls, individually. There were eleven studies [34-38,41-43,46,48-49],which only analyzed definite/probable patients and controls. Another four studies' [32-33, 39,49] participants consisted of 2 populations, definite patients and controls. Finally, a total of 2,310 participants, of which 170 definite cases, 847 definite/probable cases, 66 probable cases, 83 possible/colonized cases were available from the

Page $3 / 15$ 
included studies. Characteristics of the included studies are shown in Table 2. Details of cutoff levels and their corresponding $2 \times 2$ contingency data in each included study are shown in Table 3.

Risk of bias/quality assessment

Table 4 provides results of assessing the risk of bias, with most studies demonstrating high risk of bias. Only 2 studies [35-36] had an unclear risk of bias. In Boer' study [35], it was unclear whether the reference standard correctly classified the target condition. And there was no available data about the interval between the index test and reference standard in Passos' study [36].

The results of Meta-analysis

Diagnostic accuracy of serum BDG for PJP patients versus controls

Forest plots of sensitivity and specificity with $95 \% \mathrm{Cl}$ are shown in Figure 2a-2e for the diagnosis of Pneumocystis jirovecii pneumonia in PJP patients versus controls at various cutoff values of serum BDG $80,200,300,400$ and $500 \mathrm{pg} / \mathrm{mL}$, individually. Table 5 shows pooled point estimates of sensitivity,

specificity, LR-, LR+, DOR, Study heterogeneity $Q^{2}$, study inconsistency $\mathrm{I}^{2}$, and $\mathrm{P}$ value of publication bias for the study-specific different BDG cutoff values for diagnosing PJP based on a bivariate random-effects model. There were 19,9, 8,9,and 12 studies included in our study at different cutoff values of serum BDG $80 \mathrm{pg} / \mathrm{mL}$ [32-50], $200 \mathrm{pg} / \mathrm{mL}[32-33,40,42,44-47,50], 300$ pg/mL[32-34,40,42,44-45,50], 400 pg/mL[32-33,39-40,42,44-46,50] and BDG 500 pg/mL [32-34, 40$47,50]$, respectively. Evidence of significant publication bias was identified by Egger's test when the thresholds of serum BDG were $80,400,500 \mathrm{pg} / \mathrm{mL}$ $(P=0.007,0.037$ and 0.037 , respectively), but there were no evidence of significant publication bias when the thresholds of serum $B D G$ were $200,300 \mathrm{pg} / \mathrm{mL}$ $(P=0.114$ and 0.086 , individually). Forest plots of sensitivity and specificity for the diagnosis of Pneumocystis jirovecii pneumonia (PJP patients vs controls) at various cutoff values are shown in Figure 2a-2e. Pooled point estimates with $95 \%$ confidence regions of sensitivity/specificity and the hierarchical summary receiver-operating characteristic(HSROC) curve for the different cutoff values of serum BDG are shown in Figure 3.

Diagnostic accuracy of serum BDG for HIV-negative PJP patients versus controls subgroup

Five studies [32-33,42,44-45] reported the diagnostic accuracy of serum BDG at various cutoffs of $80,200,300,400$,and 500 pg/mL in HIV-negative PJP patients versus controls subgroup, individually. The detailed results of stratified analysis of the point estimates of sensitivity, specificity, LR+, LR-, and DOR are shown in Table 5. Except for $80 \mathrm{mg} / \mathrm{mL}$ stratum $(P=0.397)$, the heterogeneity studies in the other strata were consistently significant $(P<0.001$, for any other strata). Except for the threshold of serum BDG $80 \mathrm{mg} / \mathrm{mL}$ stratum $(P=0.087)$, no significant publication bias was performed by Egger's test $(P>0.10$, for any other strata).

Diagnostic accuracy of serum BDG for HIV-positive PJP patients versus controls subgroup

A total of seven studies [32-33, 39, 41, 44-46] allowed reproduction of the $2 \times 2$ contingency tables for HIV-positive PJP patients versus controls. From these studies, 7 BDG cutoff value of $80 \mathrm{mg} / \mathrm{mL}$ [32-33, 39, 41, 44-46] , 5 BDG cutoff value of 200mg/mL [32-33, 44-46] , 4 BDG cutoff value of 300mg/mL [32-33, 4445] , 6 BDG cutoff value of $400 \mathrm{mg} / \mathrm{mL}$ [32-33, 39, 44-46] , and 6 BDG cutoff value of $500 \mathrm{mg} / \mathrm{mL}[32-33,41$, 44-46] datasets were obtained,individually. As to various thresholds of serum BDG in HIV-positive PJP individuals, overall point estimates of sensitivity, specificity, LR-, LR+, DOR, Study heterogeneity Q2, study inconsistency $\mathrm{I} 2$, and $\mathrm{P}$ value of publication bias based on a bivariate random-effects model are also shown in Table 5 . Compared with HIV-negative patients in subgroup, LR- was lower for detecting HIV-positive persons who would develop PJP. Except for the cutoff value of serum BDG was $80 \mathrm{mg} / \mathrm{mL}$ stratum $(P=0.202)$, evidence of significant publication bias was identified by Egger's test $(P<0.10$, for any other strata).

Diagnostic accuracy of serum BDG for PJP versus colonized patients subgroup

Six studies allowed the analysis of the diagnostic ability between PJP and colonized patients at various serum BDG cutoff values [40,42,44-45,47,50]. From these studies, 6 BDG cutoff value of $80 \mathrm{mg} / \mathrm{mL}[40,42,44-45,47,50], 6 \mathrm{BDG}$ cutoff value of $200 \mathrm{mg} / \mathrm{mL}[40,42,44-45,47,50], 5$ BDG cutoff value of $300 \mathrm{mg} / \mathrm{mL}[40,42,44-45,50], 6$ BDG cutoff value of $400 \mathrm{mg} / \mathrm{mL}[40,42,44-45,47,50]$, and 6 BDG cutoff value of 500mg/mL [40,42,44-45,47,50] datasets were available. The results of stratified analyses of point estimates of sensitivity, specificity, LR+, LR-, and the DOR for serum BDG based on a bivariate randomeffects model are also shown in Table 5. Despite evidence of significant publication bias was performed (Table 5), the pooled overall LR- was low to 0.17 at a cutoff value of serum BDG $80 \mathrm{mg} / \mathrm{mL}$, resulting in the strong ability to exclude PJP when the result of PJ-qPCR is positive in BAL. No evidence of significant publication bias was performed by Egger tests $(P>0.10$, for any other strata).

\section{Discussion}

The current meta-analysis indicated that the usefulness of serum BDG at a recommended cutoff value of 80 pg /mL,measured by the Fungitell assay,had high pooled overall sensitivity $(0.94,95 \% \mathrm{Cl} 0.89-0.96)$ for the diagnostic ability of PJP individuals, similar to the previous three meta-analysis studies [52-54]. However, our stratified analysis showed that the ability to detect PJP patients was further lowered, as shown in Table 5 with a serum BDG cut-off value of 200 $\mathrm{pg} / \mathrm{mL}(0.78,95 \% \mathrm{Cl} 0.66-0.87), 300 \mathrm{pg} / \mathrm{mL}(0.77,95 \% \mathrm{Cl} 0.64-0.87), 400 \mathrm{pg} / \mathrm{mL}(0.66,95 \% \mathrm{Cl} 0.52-0.78), 500 \mathrm{pg} / \mathrm{mL}(0.59,95 \% \mathrm{Cl} 0.49-0.68)$, respectively. There are obviously differences in comparison with the previous studies $₫$ Salerno et al. [34] reported that the sensitivity was $0.91(95 \% \mathrm{Cl}, 0.83-0.99)$ at a threshold of 300 $\mathrm{pg} / \mathrm{mL}$ and Esteves et al. [39] reported that the sensitivity was 0.928 at a threshold of $400 \mathrm{pg} / \mathrm{mL}$. Secondly, our meta-analysis also analyzed the diagnostic sensitivity of serum BDG to PJP at various cutoff values in different HIV states, and the results showed that more sensitive in patients with HIV than in those without ,cutoff value of $80 \mathrm{pg} / \mathrm{mL}$ (0.94 vs. 0.87 ), $200 \mathrm{pg} / \mathrm{mL}$ (0.93 vs. 0.66), $300 \mathrm{pg} / \mathrm{mL}$ (0.87 vs. 0.64$), 400 \mathrm{pg} / \mathrm{mL}(0.74 \mathrm{vs.} 0.54), 500 \mathrm{pg} / \mathrm{mL}$ (0.70 vs. 0.47),individually. To our knowledge, it was the first meta-analysis study to stratify the diagnostic sensitivity of plasma BDG to PJP, and there was high diagnostic sensitivity at various thresholds in HIV-positive populations, but the diagnostic sensitivity of other subgroups was not ideal. It may be interpreted

Page $4 / 15$ 
that the superior diagnostic sensitivity of BDG in HIV patients was related to the higher burden of PJ. Finally, we particularly analyzed a subgroup of the PJP patients versus possible/colonized patients, which also had good pooled overall diagnostic sensitivity $(0.86,95 \% 0.73-0.93)$ at a threshold of 80 pg/mL, indicating that serum BDG detection could effectively distinguish PJP from colonization. When PJ-PCR was introduced, it significantly increased the sensitivity to the diagnostic sensitivity of PJP, resulting in an increase in the number of false positive cases of PJP [28,56-57]. Given the high sensitivity of BDG detection in serum, negative serum B-D-glucan assay can rule out PJP in patients at risk for disease, particularly those who's a BAL test is not feasible [55].

Although our meta-analysis also indicated that the specificity of BDG for the diagnosis of PJP was moderate at the recommended threshold of $80 \mathrm{mg} / \mathrm{mL}$, with a pooled overall specificity of $0.76(95 \% \mathrm{Cl}, 0.65-0.85), 0.68(95 \% \mathrm{Cl}, 0.35-0.89)$ for HIV-negative PJP patients subgroup, and 0.71 (95\%Cl,0.49-0.86) for HIVpostive patients subgroup, similar to what was previously described[52-54]. Nevertheless,our meta-analysis estimated that the combination of the BALF analyses PJ-PCR and serum BDG yielded a pooled overall specificity of $0.82(95 \% \mathrm{Cl}, 0.73-0.88)$ at the lowest cut-off level of $80 \mathrm{mg} / \mathrm{mL}$. The present metaanalysis described that serum BDG with cut-off level $\geq 200 \mathrm{pg} / \mathrm{ml}$ yielded specificity above $94 \%$ as well, suggesting a very high diagnostic performance for PJP patients.As a result, we suggest that PJP could be excluded by raising BDG threshold or combining with BALF PJ-PCR results.In particular, a higher cutoff value is appropriate for screening in populations whose BALF samples are not readily available. However, further studies are needed to confirm the validity of this recommendation.

Nevertheless,false positive tests for serum BDG may occur up to $35 \%$ of cases [41]. In fact, $\beta$-glucan is not specific to PCP, it is also included in the criteria for deep-seated fungal diseases,such as invasive candidiasis and invasive aspergillosis [29]. False-positive results from serum BDG assays are mostly due to several conditions, presenting in patients undergoing hemodialysis through cellulose membranes, receipt of albumin and immunoglobulin products,

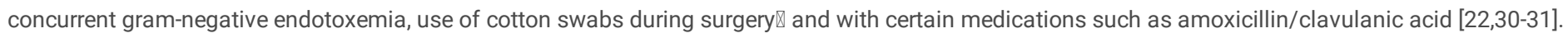
Therefore, if only serum BDG positive results are obtained, the diagnosis of PJP should be interpreted with care to avoid misdiagnosis and delay the patient's condition, and additional clinical and laboratory information such as PCR, BAL, computed tomography (CT) scan or autopsy will be required to validate the diagnosis of PJP.

In the clinical setting, a rapid laboratory BDG assay is critical to diagnose or rule out PJP, which may allow physicians to postpone or even skip the BAL.Although most of the articles included in our meta-analysis were retrospective studies, diagnostic ability of serum BDG LR+ to diagnose PJP in HIVpositive, HIV-negative, or PJ-PCR-positive people was judged to be 'weak' at the recommended threshold of 80pg/mL. A positive serum BDG in these populations should prompt a comprehensive microbiological study to allow the diagnosis of bacterial and fungal diagnosis other than PJP. And it appears more and more clearly that serum BDG detection of PJ appears to be a more appropriate strategy for the diagnosis of PJP in HIV patients. Our findings, if confirmed, may indicate that the optimal cut-off level for diagnosing PCP may be different from serum BDG for invasive fungal infections. However, the above findings should be explained in terms of the high statistical heterogeneity noted in all the studies we analyzed. The presentation of the patient and the presence or absence of specimens as described above will influence the approach to the interpretation of the test.In such cases, choosing a higher threshold value can help identify those patients with clinically significant disease. Raw patient data were unavailable, so the optimum cut-offs were unable to determine.Future studies are needed to clarify this topic.

Some limitations should be addressed. Firstly, we could not access unpublished reports, which may allow publication bias. Secondly, most of the studies included in our meta-analysis were retrospective case-control studies, and there were significant issues of selection bias when evaluating the quality of the included studies. We found significant heterogeneity in the pooled sensitivity and specificity estimates. This may owe to the differences in the target population and the biases associated with patient selection in these case-control studies. Thirdly, several studies do not evaluate serum BDG as the sole purpose of diagnosing PJP, which may lead to an overestimate of sensitivity and specificity. Forthly, some studies did not perform hierarchical assessment of the diagnostic ability of serum BDG for PJP or the stratification strategies were different among studies, resulting in data loss or inaccuracy. Fifthly, the time of specimen collection is critical. The time interval between the serum BDG test and the patient's diagnosis of PJP is different between studies, or some specimens have been collected before the use of prophylactic therapies, which may affect the results of serum BDG test. Finally, the included trials were not large enough for us to obtain sufficient data to explore the potential interference between the various factors contributing to significant heterogeneity. These factors may have potential effects on the findings in the current study. As a result,the findings of this meta-analysis need to be confirmed by more welldesigned and large-scale investigations.

In conclusion, the main strength of this study is that the stratified systematic review and meta-analysis of existing studies, although most of the studies included were retrospective controlled studies, were sufficient to assure us that serum BDG tested by the Fungitell assay at various thresholds differed significantly in the ability to diagnose PJP patients with and without HIV. The current meta-analysis suggests that a negative serum-BG result can be used as a laboratory indicator to "exclude" PJP, especially in patients without HIV. When positive BDG is applied to patients, the results should be interpreted cautiously and in conjunction with clinical and radiological findings. BAL is the preferred specimen for the diagnosis of PJP, in which the PJ-PCR result is highly sensitive and specificity. However, there are some limitations in differentiating patients with infection or colonization. Our meta-analysis showed that the positive results of serum BDG combined with PJ-PCR have high sensitivity and specificity in differentiating infection from colonization. This meta-analysis suggests that the optimal positive threshold for serum BDG requires better definition and clinical validation rather than the recommended cutoff of $80 \mathrm{pg} / \mathrm{mL}$ in the diagnosis of PJP as well. And these cutoff values could be further refined in additional studies that focus on populations that are as homogeneous as possible. More studies are also needed, particularly large prospective cohort studies, to confirm the diagnosis value of serum BDG detection.

\section{Declarations}

\section{Conflicts of interest}

All authors declare that there is no conflict of interest. 
Funding This study was funded by the National High Technology Research and Development Program of China (863 Program), No. 2011 AA02A111.

Availability of data and material (data transparency) All data generated or analysed during this study are included in this published article.

Code availability Stata 12.0(6irr omjb3xob \$m9x k7uh u7lt y258 a51y tphc).

Authors' contributions All authors contributed to the study conception and design. Material preparation, data collection and analysis were performed by Wenzhang Long and Kunting Xiao. The first draft of the manuscript was written by Wenzhang Long and all authors commented on previous versions of the manuscript. All authors read and approved the final manuscript.

Ethics approval This is a meta-analysis study. The Yongchuan Hospital Research Ethics Committee of Chongqing Medical University has confirmed that no ethical approval is required.

Consent to participate This is a meta-analysis study that does not require informed consent.

Consent for publication Written informed consent for publication was obtained from all participants.

\section{References}

1. Limper AH, Adenis A, Le T, Harrison TS. Fungal infections in HIV/AIDS. Lancet Infect Dis. 2017; 17: e334-e343.

2. Suk CW, Bai KJ, Yu MC, et al. Coinfection of Pneumocystis jirovecii pneumonia and pulmonary tuberculosis in a nonHIV-infected patient. J Microbiol Immunol Infect. 2015;48: 711-712.

3. Morris A, Lundgren JD, Masur H, et al. Current epidemiology of Pneumocystis pneumonia. Emerg Infect Dis. 2004;10: 1713-1720.

4. Anonymous. 2009. HIV/AIDS surveillance report, p. 19. Centers for Disease Control and Prevention, Atlanta, GA.

5. Caldero 'n, E. J., S. Gutie 'rrez-Rivero, I. Durand-Joly, and E. Dei-Cas. 2010.Pneumocystis infection in humans: diagnosis and treatment. Expert Rev. Anti Infect. Ther. 8:683-701.

6. Kovacs, J. A., and H. Masur. 2009. Evolving health effects of Pneumocystis:one hundred years of progress in diagnosis and treatment. JAMA 301:25782585 .

7. Shelhamer JH, Gill VJ, Quinn TC, et al. The laboratory evaluation of opportunistic pulmonary infections. Ann Intern Med 1996;124(6):585-599

8. Thomas, C. F., Jr., and A. H. Limper. 2004. Pneumocystis pneumonia.N. Engl. J. Med. 350:2487-2498.

9. Saito K, Nakayamada S, Nakano K, Tokunaga M, Tsujimura Set al. Detection of Pneumocystis carinii by DNA amplification in patients with connective tissue diseases: re-evaluation of clinical features of P. carinii pneumonia in rheumatic diseases. Rheumatology (0xford) 2004 ; 43: 479-85.

10. Wakefield AE, Pixley FJ, Banerji S, Sinclair K, Miller RF et al.Detection of Pneumocystis carinii with DNA amplification.Lancet 1990; 336: 451-3.

11. Larsen HH, Masur H, Kovacs JA, Gill VJ, Silcott VA et al. Development and evaluation of a quantitative, touch-down, real-time PCR assay for diagnosing Pneumocystis carinii pneumonia.J. Clin. Microbiol. 2002; 40: 490-4.

12. Takahashi T, Goto M, Endo T, Nakamura T, Yusa N et al.Pneumocystis carinii carriage in immunocompromised patients with and without human immunodeficiency virus infection.J. Med. Microbiol. 2002; 51: 611-14.

13. Wilkin A, Feinberg J. Pneumocystis carinii pneumonia: a clinical review. Am Fam Physician 1999; 60(6):1699-708, 713-4.

14. Guidelines for the prevention and treatment of opportunistic infections in HIV-infected adults and adolescents: recommendations from the Centers for Disease Control and Prevention, the National Institutes of Health, and the HIV Medicine Association of the Infectious Diseases Society of America. Accessed 10/10/2016,Page numbers B-1 to B-16.

15. Gruden JF, Huang L, Turner J, et al. High-resolution CT in the evaluation of clinically suspected Pneumocystis carinii pneumonia in AIDS patients with normal, equivocal, or nonspecific radiographic findings. AJR Am J Roentgenol 1997;169(4):967-975.

16. Onishi A, Sugiyama D, Kogata Y, Saegusa J, Sugimoto T, Kawano S, Morinobu A,Nishimura K, Kumagai S. Diagnostic Accuracy of Serum 1,3- $\beta$-D-Glucan for Pneumocystis jiroveci Pneumonia, Invasive Candidiasis, and Invasive Aspergillosis: Systematic Review and Meta-Analysis. J Clin Microbiol. 2012;50(1):7-15.

17. Li WJ, Guo YL, Liu TJ, Wang K, Kong JL.Diagnosis of pneumocystis pneumonia using serum (1-3)- $\beta$-D-Glucan:a bivariate meta-analysis and systematic review. Thorac Dis. 2015; 7(12): 2214-25.

18. Matsumura $Y$, Ito $Y$, linuma $Y$, Yasuma $K$, Yamamoto $M$, Matsushima A, Nagao $M$, Takakura S, Ichiyama S. Quantitative real-time PCR and the (1 $\rightarrow 3)-\beta-D-$ glucan assay for differentiation between Pneumocystis jirovecii pneumonia and colonization. Clin Microbiol Infect. 2012 Jun;18(6):591-7.

19. Dichtl K, Seybold U, Wagener J. Evaluation of a Turbidimetric $\beta$-d-Glucan Test for Detection of Pneumocystis jirovecii Pneumonia. J Clin Microbiol. 2018 Jun 25;56(7):e00286-18.

20. De Pauw B, Walsh TJ, Donnelly JP, et al; European Organization for Research and Treatment of Cancer/Invasive Fungal Infections Cooperative Group; National Institute of Allergy and Infectious Diseases Mycoses Study Group (EORTC/MSG) Consensus Group. Revised definitions of invasive fungal disease from the European Organization for Research and Treatment of Cancer/Invasive Fungal Infections Cooperative Group and the National Institute of Allergy and Infectious Diseases Mycoses Study Group (EORTC/MSG) Consensus Group. Clin Infect Dis 2008; 46:1813-21.

21. Morjaria S, Frame J, Franco-Garcia A, Geyer A, Kamboj M, Babady NE. Clinical Performance of $(1,3)$ Beta-D Glucan for the Diagnosis of Pneumocystis Pneumonia (PCP) in Cancer Patients Tested With PCP Polymerase Chain Reaction. Clin Infect Dis. 2019 Sep 27;69(8):1303-1309. 
22. Ellis M, Al-Ramadi B, Finkelman M, Hedstrom U,Kristensen J, Ali-Zadeh H, et al. Assessment of the clinical utility of serial b-D-glucan concentrations in patients with persistent neutropenic fever. J Med Microbiol 2008;57:287 e 95.

23. Whiting PF, Rutjes AW, Westwood ME, Mallett S, Deeks JJ, Reitsma JB, Leeflang MM, Sterne JA, Bossuyt PM; QUADAS-2 Group. QUADAS-2: a revised tool for the quality assessment of diagnostic accuracy studies. Ann Intern Med. 2011 Oct 18;155(8):529-36.

24. Rutter CM, Gatsonis CA. A hierarchical regression approach to meta-analysis of diagnostic test accuracy evaluations. Stat Med 2001;20(19):2865-2884.

25. Harbord RM, Deeks JJ, Egger M, Whiting P, Sterne JA. A unification of models for meta-analysis of diagnostic accuracy studies. Biostatistics 2007;8(2):239-251.

26. Higgins JP, Thompson SG,Deeks JJ, Altman DG. Measuring inconsistency in meta-analyses. BMJ 2003;327:557-60.

27. Egger M, Davey Smith G, Schneider M, Minder C. Bias in meta-analysis detected by a simple,graphical test.BMJ1997;315:629-34.

28. Huang L, Crothers K, Morris A, Groner G, Fox M, Turner JR, et al.Pneumocystis colonization in HIV-infected patients. J Eukaryot Microbiol 2003; 50(Suppl): 616-7.

29. Marty FM, Koo S. Role of (1->3)-beta-D-glucan in the diagnosis of invasive aspergillosis. Med Mycol 2009; 47 Suppl 1: S233-40.

30. Karageorgopoulos DE, Qu JM, Korbila IP, Zhu YG,Vasileiou VA,Falagas ME.Accuracy of b-D-glucan for the diagnosis of Pneumocystis jirovecii pneumonia: a meta-analysis. Clin Microbiol Infect 2013;19:39 e 49.

31. Digby J, Kalbfleisch J, Glenn A, Larsen A, Browder W,Williams D, et al. Serum glucan levels are not specific for presence of fungal infections in intensive care unit patients. Clin Diagn Lab Immunol 2003;10:882 e 5 .

32. Persat, F.; Ranque, S.; Derouin, F.; Michel-Nguyen, A.; Picot, S.; Sulahian, A. (2008). Contribution of the (1->3)- -D-Glucan Assay for Diagnosis of Invasive Fungal Infections. Journal of Clinical Microbiology, 46(3), 1009-1013. doi:10.1128/JCM.02091-07

33. Desmet, S.; Van Wijngaerden, E.; Maertens, J.; Verhaegen, J.; Verbeken, E.; De Munter, P.; Meersseman, W.; Van Meensel, B.; Van Eldere, J.; Lagrou, K. (2009). Serum (1-3)- -D-Glucan as a Tool for Diagnosis of Pneumocystis jirovecii Pneumonia in Patients with Human Immunodeficiency Virus Infection or Hematological Malignancy. Journal of Clinical Microbiology, 47(12), 3871-3874. doi:10.1128/JCM.01756-09.

34. Salerno D, Mushatt D, Myers L, Zhuang Y, de la Rua N, Calderon EJ, Welsh DA. Serum and bal beta-D-glucan for the diagnosis of Pneumocystis pneumonia in HIV positive patients. Respir Med. 2014 Nov;108(11):1688-95. doi: 10.1016/j.rmed.2014.09.017.

35. de Boer MG, Gelinck LB, van Zelst BD, van de Sande WW, Willems LN, van Dissel JT, de Jonge R, Kroon FP. $\beta$-D-glucan and S-adenosylmethionine serum levels for the diagnosis of Pneumocystis pneumonia in HIV-negative patients: a prospective study. J Infect. 2011 Jan;62(1):93-100. doi: 10.1016/j.jinf.2010.10.007.

36. Passos AIM, Dertkigil RP, Ramos MC, Busso-Lopes AF, Tararan C, Ribeiro EO, Schreiber AZ, Trabasso P, Resende MR, Moretti ML. Serum markers as an aid in the diagnosis of pulmonary fungal infections in AIDS patients. Braz J Infect Dis. 2017 Nov-Dec;21(6):606-612. doi: 10.1016/j.bjid.2017.07.002.

37. Mercier T, Guldentops E, Patteet S, Beuselinck K, Lagrou K, Maertens J. Beta-d-Glucan for Diagnosing Pneumocystis Pneumonia: a Direct Comparison between the Wako $\beta$-Glucan Assay and the Fungitell Assay. J Clin Microbiol. 2019 May 24;57(6):e00322-19. doi: 10.1128/JCM.00322-19.

38. Held J, Koch MS, Reischl U, Danner T, Serr A. Serum $(1 \rightarrow 3)-\beta$-D-glucan measurement as an early indicator of Pneumocystis jirovecii pneumonia and evaluation of its prognostic value. Clin Microbiol Infect. 2011 Apr;17(4):595-602. doi: 10.1111/j.1469-0691.2010.03318.x.

39. Esteves F, Lee CH, de Sousa B, Badura R, Seringa M, Fernandes C, Gaspar JF, Antunes F, Matos O. (1-3)-beta-D-glucan in association with lactate dehydrogenase as biomarkers of Pneumocystis pneumonia (PCP) in HIV-infected patients. Eur J Clin Microbiol Infect Dis. 2014 Jul;33(7):1173-80. doi: 10.1007/s10096-014-2054-6.

40. Damiani C, Le Gal S, Lejeune D, Brahimi N, Virmaux M, Nevez G, Totet A. Serum (1->3)-beta-D-glucan levels in primary infection and pulmonary colonization with Pneumocystis jirovecii. J Clin Microbiol. 2011 May;49(5):2000-2. doi: 10.1128/JCM.00249-11.

41. Sax PE, Komarow L, Finkelman MA, Grant PM, Andersen J, Scully E, Powderly WG, Zolopa AR; AIDS Clinical Trials Group Study A5164 Team. Blood (1->3)beta-D-glucan as a diagnostic test for HIV-related Pneumocystis jirovecii pneumonia. Clin Infect Dis. 2011 Jul 15;53(2):197-202. doi: 10.1093/cid/cir335. PMID: 21690628; PMCID: PMC3165964.

42. Szvalb AD, Malek AE, Jiang Y, Bhatti MM, Wurster S, Kontoyiannis DP. Serum (1,3)-Beta-d-Glucan has suboptimal performance for the diagnosis of Pneumocystis jirovecii pneumonia in cancer patients and correlates poorly with respiratory burden as measured by quantitative PCR. J Infect. 2020 Sep;81(3):443-451. doi: 10.1016/j.jinf.2020.07.003. Epub 2020 Jul 7.

43. Costa JM, Botterel F, Cabaret O, Foulet F, Cordonnier C, Bretagne S. Association between circulating DNA, serum (1->3)- $\beta$-D-glucan, and pulmonary fungal burden in Pneumocystis pneumonia. Clin Infect Dis. 2012 Jul;55(2):e5-8. doi: 10.1093/cid/cis412. Epub 2012 Apr 20.

44. Engsbro AL, Najat S, Jørgensen KM, Kurtzhals JAL, Arendrup MC. Diagnostic accuracy of the 1,3- $\beta$-D-glucan test for pneumocystis pneumonia in a tertiary university hospital in Denmark: A retrospective study. Med Mycol. 2019 Aug 1;57(6):710-717. doi: 10.1093/mmy/myy129.

45. Damiani C, Le Gal S, Da Costa C, Virmaux M, Nevez G, Totet A. Combined quantification of pulmonary Pneumocystis jirovecii DNA and serum (1->3)- $\beta$-Dglucan for differential diagnosis of pneumocystis pneumonia and Pneumocystis colonization. J Clin Microbiol. 2013 Oct;51(10):3380-8. doi: 10.1128/JCM.01554-13. Epub 2013 Jul 31.

46. Hammarström H, Grankvist A, Broman I, Kondori N, Wennerås C, Gisslen M, Friman V. Serum-based diagnosis of Pneumocystis pneumonia by detection of Pneumocystis jirovecii DNA and 1,3-B-D-glucan in HIV-infected patients: a retrospective case control study. BMC Infect Dis. 2019 Jul 23;19(1):658. doi: 10.1186/s12879-019-4289-4.

47. Morjaria S, Frame J, Franco-Garcia A, Geyer A, Kamboj M, Babady NE. Clinical Performance of $(1,3)$ Beta-D Glucan for the Diagnosis of Pneumocystis Pneumonia (PCP) in Cancer Patients Tested With PCP Polymerase Chain Reaction. Clin Infect Dis. 2019 Sep 27;69(8):1303-1309. doi: 10.1093/cid/ciy1072. 
48. Desoubeaux G, Chesnay A, Mercier V, Bras-Cachinho J, Moshiri P, Eymieux S, De Kyvon MA, Lemaignen A, Goudeau A, Bailly É. Combination of ß-(1, 3)-Dglucan testing in serum and qPCR in nasopharyngeal aspirate for facilitated diagnosis of Pneumocystis jirovecii pneumonia. Mycoses. 2019 Nov;62(11):1015-1022. doi: 10.1111/myc.12997. Epub 2019 Sep 18.

49. De Carolis E, Marchionni F, Torelli R, Angela MG, Pagano L, Murri R, De Pascale G, De Angelis G, Sanguinetti M, Posteraro B. Comparative performance evaluation of Wako $\beta$-glucan test and Fungitell assay for the diagnosis of invasive fungal diseases. PLoS One. 2020 Jul 29;15(7):e0236095. doi: 10.1371/journal.pone.0236095.

50. Mercier T, Aissaoui N, Gits-Muselli M, Hamane S, Prattes J, Kessler HH, Mareković I, Pleško S, Steinmann J, Scharmann U, Maertens J, Lagrou K, Denis B, Bretagne S, Alanio A. Variable Correlation between Bronchoalveolar Lavage Fluid Fungal Load and Serum-(1,3)- $\beta$-d-Glucan in Patients with Pneumocystosis-A Multicenter ECMM Excellence Center Study. J Fungi (Basel). 2020 Dec 1;6(4):327. doi: 10.3390/jof6040327.

51. Jaeschke R, Guyatt GH, Sackett DL. Users' guides to the medical literature. III. How to use an article about a diagnostic test. B. What are the results and will they help me in caring for my patients? The Evidence-Based Medicine Working Group. JAMA 1994;271(9):703-707.

52. Karageorgopoulos DE, Qu JM, Korbila IP, Zhu YG, Vasileiou VA, Falagas ME. Accuracy of $\beta$-D-glucan for the diagnosis of Pneumocystis jirovecii pneumonia: a meta-analysis. Clin Microbiol Infect. 2013 Jan;19(1):39-49.

53. Li WJ, Guo YL, Liu TJ, Wang K, Kong JL. Diagnosis of pneumocystis pneumonia using serum (1-3)- $\beta$-D-Glucan: a bivariate meta-analysis and systematic review. J Thorac Dis. 2015 Dec;7(12):2214-25.

54. Del Corpo O, Butler-Laporte G, Sheppard DC, Cheng MP, McDonald EG, Lee TC. Diagnostic accuracy of serum (1-3)- $\beta$-D-glucan for Pneumocystis jirovecii pneumonia: a systematic review and meta-analysis. Clin Microbiol Infect. 2020 Sep;26(9):1137-1143.

55. Alanio A, Hauser PM, Lagrou K, et al. ECIL guidelines for the diagnosis of Pneumocystis jirovecii pneumonia in patients with haematological malignancies and stem cell transplant recipients. J Antimicrob Chemother 2016; 71(9): 2386-96.

56. Jarboui MA, Sellami A, Sellami H, Cheikhrouhou F, Makni F, Ben Arab N,et al. Molecular diagnosis of Pneumocystis jirovecii pneumonia in immunocompromised patients. Mycoses 2010; 53: 329-33.

57. Carmona EM, Limper AH. Update on the diagnosis and treatment of Pneumocystis pneumonia. Ther Adv Respir Dis 2011; 5: 41-59.

\section{Tables}

Table 1 Definitions of pneumocystis jirovecii infection [20-21]

\begin{tabular}{|c|c|c|c|c|}
\hline Infection & Definite & Probable & Possible/colonized & Not PJP \\
\hline $\begin{array}{l}\text { Pneumocystis } \\
\text { jirovecii } \\
\text { pneumonia }\end{array}$ & $\begin{array}{l}\text { 1.Suggestive respiratory symptoms }{ }^{a} \text {;and } \\
\text { 2. PJ-PCR, detected in BAL and/or BW; } \\
\text { and } 3 \text {. Documented PJ in } \\
\text { histopathology,GMS cytology, and/or } \\
\text { DFA. }\end{array}$ & $\begin{array}{l}\text { 1. Compatible risk factors } \\
\text { with clinical presentation } \\
\text {;and } 2 . \text { PJ-PCR, detected } \\
\text { in BAL and/or BW. }\end{array}$ & $\begin{array}{l}\text { 1.Nonspecific clinical } \\
\text { presentation without } \\
\text { predisposing risk factors; and } \\
\text { 2. PJ-PCR, detected in BAL } \\
\text { and/or BW. }\end{array}$ & $\begin{array}{l}\text { 1.Negative } \\
\text { histopathology/cytology/PJ- } \\
\text { PCR with or without an } \\
\text { established alternate } \\
\text { diagnosis. }\end{array}$ \\
\hline
\end{tabular}

Abbreviations: BAL, bronchoalveolar lavage; BDG, beta-D glucan; BW, bronchial washing; DFA, direct fluorescent antibody; GMS,Gomori methenamine silver stain; PJ, pneumocystis jirovecii; PJP, pneumocystis jirovecii pneumonia; PCR, polymerase chain reaction.

a Shortness of breath, dyspnea on exertion, increased $\mathrm{O}_{2}$ requirements, dry or productive cough, and hemoptysis.

Table 2 Characteristics of studies included in the meta-analysis 


\begin{tabular}{|c|c|c|c|c|c|c|c|c|c|c|c|}
\hline \multirow[t]{2}{*}{ Study source } & \multirow[t]{2}{*}{ Region } & \multirow[t]{2}{*}{ Language } & \multirow{2}{*}{$\begin{array}{l}\text { Cutoff } \\
\text { values of } \\
\text { BDG(pg/mL) }\end{array}$} & \multicolumn{2}{|c|}{$\begin{array}{l}\text { No. of } \\
\text { patients }\end{array}$} & \multicolumn{2}{|c|}{$\begin{array}{l}\text { Mean or } \\
\text { median age } \\
(y r)\end{array}$} & \multicolumn{2}{|c|}{ Female } & \multirow[t]{2}{*}{$\begin{array}{l}\text { Target } \\
\text { population }\end{array}$} & \multirow[t]{2}{*}{$\begin{array}{l}\text { Control } \\
\text { population }\end{array}$} \\
\hline & & & & $\mathrm{T}$ & C & $\mathrm{T}$ & C & $\mathrm{T}$ & C & & \\
\hline $\begin{array}{l}\text { Sejal Morjaria } \\
{[47] 2018}\end{array}$ & Spain & English & 80 & 53 & 385 & 57 & 56 & 15 & 164 & $\begin{array}{l}\text { Patients with } \\
\text { various } \\
\text { underlying } \\
\text { diseases }\end{array}$ & $\begin{array}{l}\text { Patients with } \\
\text { various } \\
\text { underlying } \\
\text { diseases }\end{array}$ \\
\hline Costa[43] 2012 & France & English & 80 & 36 & 34 & NA & NA & NA & NA & $\begin{array}{l}\text { Patients with } \\
\text { various } \\
\text { underlying } \\
\text { diseases }\end{array}$ & $\begin{array}{l}\text { Patients with } \\
\text { various } \\
\text { underlying } \\
\text { diseases }\end{array}$ \\
\hline $\begin{array}{l}\text { Desoubeaux } \\
\text { [48]2019 }\end{array}$ & France & English & 80 & 48 & 48 & 61 & 60 & 16 & 16 & $\begin{array}{l}\text { Patients with } \\
\text { various } \\
\text { underlying } \\
\text { diseases }\end{array}$ & $\begin{array}{l}\text { Patients with } \\
\text { various } \\
\text { underlying } \\
\text { diseases }\end{array}$ \\
\hline Damiani[45] 2013 & France & English & 80 & 46 & 45 & 59 & 56 & 12 & 16 & $\begin{array}{l}\text { Patient with } \\
\text { various } \\
\text { underlying } \\
\text { diseases }\end{array}$ & $\begin{array}{l}\text { Patient with } \\
\text { various } \\
\text { underlying } \\
\text { diseases } \\
\text { and no IFD }\end{array}$ \\
\hline Engsbro[44] 2018 & Denmark & English & 80 & 19 & 24 & 53 & 50 & NA & NA & $\begin{array}{l}\text { Patient with } \\
\text { various } \\
\text { underlying } \\
\text { diseases }\end{array}$ & $\begin{array}{l}\text { Patients with } \\
\text { various } \\
\text { underlying } \\
\text { diseases }\end{array}$ \\
\hline Szvalb[42] 2020 & USA & English & 80 & 101 & 74 & 60.5 & 60 & 41 & 30 & $\begin{array}{l}\text { Patient with } \\
\text { cancer and no } \\
\text { HIV infection }\end{array}$ & $\begin{array}{l}\text { Patient with } \\
\text { cancer and } \\
\text { BALF PJP- } \\
\text { PCR negtive }\end{array}$ \\
\hline $\begin{array}{l}\text { Hammarström[46] } \\
2019\end{array}$ & Sweden & English & 80 & 25 & 21 & 47 & 38 & 9 & NA & $\begin{array}{l}\text { HIV-infected } \\
\text { patients }\end{array}$ & $\begin{array}{l}\text { HIV-infected } \\
\text { patients }\end{array}$ \\
\hline Desmet[33] 2009 & Belgium & English & 80 & 28 & 28 & 43 & 42 & 7 & 7 & $\begin{array}{l}\text { HIV-infected } \\
\text { patients or } \\
\text { with } \\
\text { hematological } \\
\text { malignancy }\end{array}$ & $\begin{array}{l}\text { Patients with } \\
\text { various } \\
\text { underlying } \\
\text { diseases } \\
\text { and no IFD }\end{array}$ \\
\hline Persat[32] 2007 & France & English & 80 & 20 & 27 & NA & NA & NA & NA & $\begin{array}{l}\text { Patients with } \\
\text { various } \\
\text { underlying } \\
\text { diseases }\end{array}$ & $\begin{array}{l}\text { Healthy } \\
\text { donors and } \\
\text { Patients with } \\
\text { IFD }\end{array}$ \\
\hline Sax[41] 2011 & Ireland & English & 80 & 173 & 79 & NA & NA & NA & NA & $\begin{array}{l}\text { HIV-infected } \\
\text { patients }\end{array}$ & $\begin{array}{l}\text { Patients with } \\
\text { various } \\
\text { underlying } \\
\text { diseases }\end{array}$ \\
\hline Damiani[40] 2011 & France & English & 80 & 15 & $\mathrm{~N}$ & 52 & $\mathrm{~N}$ & 4 & $\mathrm{~N}$ & $\begin{array}{l}\text { Patients with } \\
\text { various } \\
\text { underlying } \\
\text { diseases }\end{array}$ & $\mathrm{N}$ \\
\hline Esteves [39] 2014 & Portugal & English & 80 & 69 & 31 & NA & NA & NA & NA & $\begin{array}{l}\text { HIV-infected } \\
\text { patients }\end{array}$ & $\begin{array}{l}\text { HIV-infected } \\
\text { patients }\end{array}$ \\
\hline Held[38] 2011 & Germany & English & 85 & 50 & 50 & 51 & 56.5 & 17 & 25 & $\begin{array}{l}\text { Patients with } \\
\text { various } \\
\text { underlying } \\
\text { diseases }\end{array}$ & $\begin{array}{l}\text { Patients with } \\
\text { various } \\
\text { underlying } \\
\text { diseases }\end{array}$ \\
\hline Mercier[37] 2019 & Belgium & English & 80 & 116 & 114 & 64 & 59 & 52 & 45 & $\begin{array}{l}\text { Patients with } \\
\text { various } \\
\text { underlying } \\
\text { diseases }\end{array}$ & $\begin{array}{l}\text { Patients with } \\
\text { various } \\
\text { underlying } \\
\text { diseases }\end{array}$ \\
\hline Passos[36] 2017 & Brazil & English & 80 & 19 & 41 & NA & NA & NA & NA & $\begin{array}{l}\text { HIV-infected } \\
\text { patients }\end{array}$ & $\begin{array}{l}\text { HIV-infected } \\
\text { patients }\end{array}$ \\
\hline Boer[35] 2011 & Netherlands & English & 80 & 21 & 10 & 57 & 59 & 10 & 2 & $\begin{array}{l}\text { Patient with } \\
\text { various } \\
\text { underlying } \\
\text { diseases and } \\
\text { no HIV } \\
\text { infection }\end{array}$ & $\begin{array}{l}\text { Patient with } \\
\text { various } \\
\text { underlying } \\
\text { diseases } \\
\text { and no HIV } \\
\text { infection }\end{array}$ \\
\hline Salerno[34] 2014 & USA & English & 80 & 46 & 62 & 43 & 45 & 14 & 19 & $\begin{array}{l}\text { HIV-infected } \\
\text { patients }\end{array}$ & $\begin{array}{l}\text { HIV-infected } \\
\text { patients }\end{array}$ \\
\hline
\end{tabular}




\begin{tabular}{|c|c|c|c|c|c|c|c|c|c|c|c|}
\hline $\begin{array}{l}\text { Toine Mercier[50] } \\
2020\end{array}$ & Belgium & English & 80 & 117 & 30 & NA & NA & NA & NA & $\begin{array}{l}\text { Patients with } \\
\text { various } \\
\text { underlying } \\
\text { diseases }\end{array}$ & $\begin{array}{l}\text { patients with } \\
\text { Pneumocytis } \\
\text { carriage }\end{array}$ \\
\hline Carolis[49] 2020 & Italy & English & 80 & 17 & 187 & 52 & 54 & 10 & 97 & $\begin{array}{l}\text { Patients with } \\
\text { various } \\
\text { underlying } \\
\text { diseases }\end{array}$ & $\begin{array}{l}\text { Patients with } \\
\text { various } \\
\text { underlying } \\
\text { diseases } \\
\text { and no IFD }\end{array}$ \\
\hline
\end{tabular}

BDG, (1-3)-ß-D-Glucan; IFD, invasive fungal disease; T,Target population;C,control population; NA, not available; N, there were no control patients.

Table 3 Diagnostic performance for Pneumocystis jiroveci pneumonia according to data extracted from different studies

NA, not available.

Table 4 Results of assessing risk of bias based on QUADAS-2 in the studies

\begin{tabular}{|c|c|c|c|c|c|}
\hline Study source & Patient Selection & Index Test & Reference Standard & Flow and Timing & risk of bias \\
\hline Sejal Morjaria [47]2018 & High & Low & Low & High & High \\
\hline Costa[43] 2012 & High & Low & High & High & High \\
\hline Desoubeaux [48]2019 & High & Low & Low & Low & High \\
\hline Damiani[45] 2013 & High & Low & Low & High & High \\
\hline Rogina[51] 2020 & High & Low & Low & Low & High \\
\hline Engsbro[44] 2018 & High & Low & Low & Low & High \\
\hline Szvalb[42] 2020 & High & Low & Low & High & High \\
\hline Hammarström[46] 2019 & High & Low & Low & Low & High \\
\hline MENG Xiangchen[46] 2018 & High & Low & Low & Unclear & High \\
\hline Desmet[33] 2009 & High & Low & Low & Low & High \\
\hline Persat[32] 2007 & High & Low & Low & Unclear & High \\
\hline Sax[41] 2011 & High & Low & Low & Unclear & High \\
\hline Damiani[40] 2011 & High & Low & Low & High & High \\
\hline Esteves [39] 2014 & High & Low & Low & Unclear & High \\
\hline Held[38] 2011 & High & Low & Low & Low & High \\
\hline Mercier[37] 2019 & High & Low & Low & Low & High \\
\hline Passos[36] 2017 & Low & Low & Low & Unclear & Unclear \\
\hline Boer[35] 2011 & Low & Low & Unclear & Low & Unclear \\
\hline Salemo[34] 2014 & High & Low & Low & Unclear & High \\
\hline Toine Mercier[50] 2020 & High & Low & Low & Unclear & High \\
\hline Carolis[49] 2020 & High & Low & Low & Low & High \\
\hline
\end{tabular}

Low=low risk;High=high risk; Unclear=unclear risk.

\section{Table 5 Overall predictive values and stratified analyses of diagnostic values}

$\mathrm{NC}$,it could not calculate numerical derivatives because of missing values $(\mathrm{fp}=0)$ encountered;C, $\mathrm{S}, \mathrm{W}$, and $\mathrm{N}$, evidence level for diagnostic ability,indicates "conclusive", "strong", "weak", and " negligible",respectively;LR+,positive likelihood ratio;LR-,negative likelihood ratio.

\section{Figures}




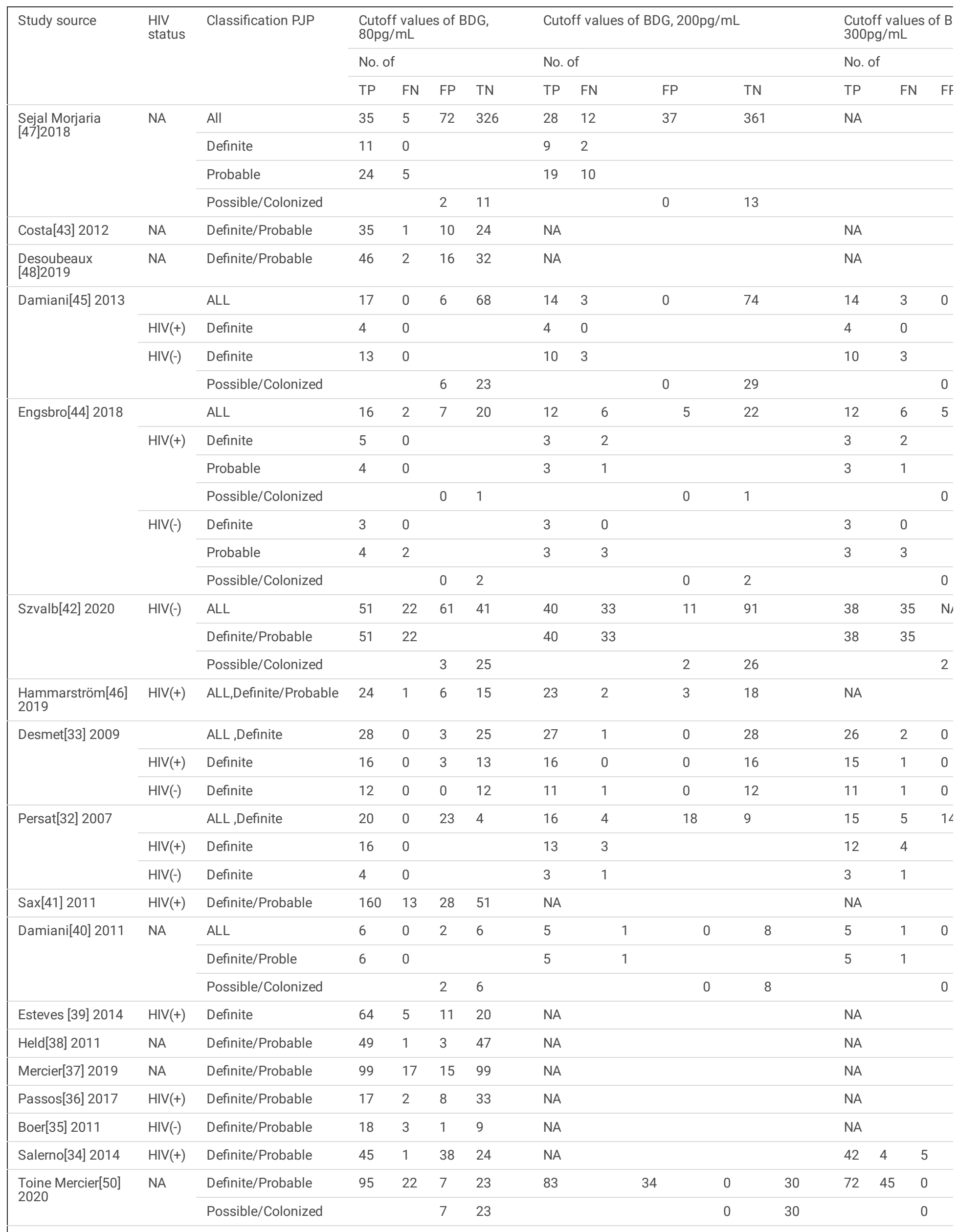




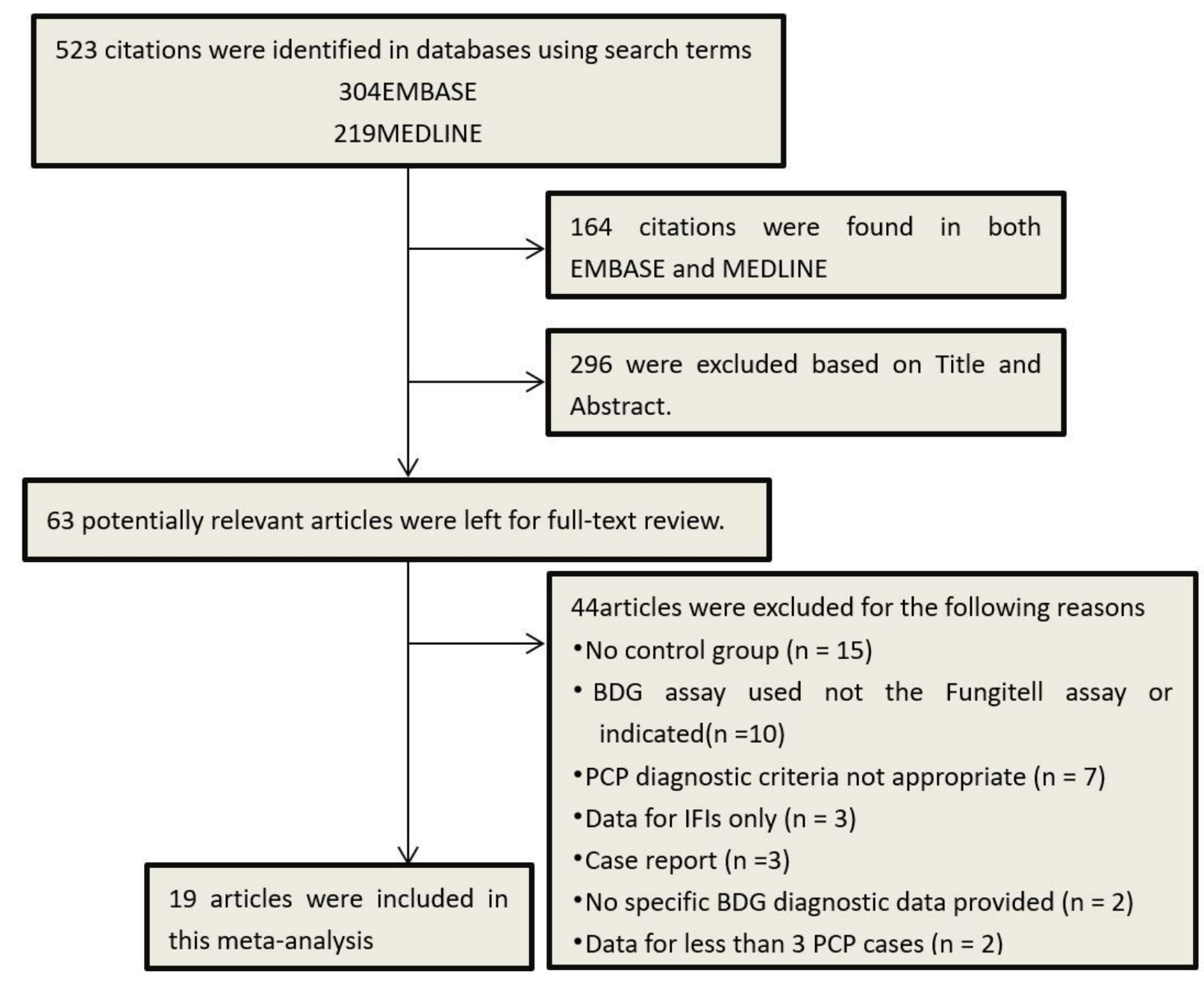

Figure 1

Flow chart of procedures in literature search for eligible studies 


\begin{tabular}{|c|c|c|c|c|c|c|c|c|c|c|}
\hline $\begin{array}{l}\text { No. } \\
\text { data } \\
\text { units }\end{array}$ & $\begin{array}{l}\text { Cutoff } \\
\text { value of } \\
\text { BDG,pg/mL }\end{array}$ & $\begin{array}{l}\text { Sensitivity } \\
(95 \% \mathrm{Cl})\end{array}$ & $\begin{array}{l}\text { Specificity } \\
(95 \% \mathrm{Cl})\end{array}$ & $\begin{array}{l}\text { LR+ } \\
(95 \% \mathrm{Cl})\end{array}$ & Level & $\begin{array}{l}\text { LR- } \\
(95 \% \mathrm{Cl})\end{array}$ & Level & $\begin{array}{l}\text { DOR } \\
(95 \% \mathrm{Cl})\end{array}$ & $\begin{array}{l}\text { Study } \\
\text { heterogeneity } \\
\text { (Chi-square): } \\
\text { LRT_Q }\end{array}$ & $\begin{array}{l}P \\
\text { value }\end{array}$ \\
\hline \multicolumn{11}{|c|}{ PJP patients versus controls } \\
\hline \multirow[t]{2}{*}{19} & 80 & 0.94 & 0.76 & 3.99 & W & 0.08 & $\mathrm{C}$ & 48.56 & 36.74 & $<0.001$ \\
\hline & & $(0.89,0.96)$ & $\begin{array}{l}(0.65- \\
0.85)\end{array}$ & $(2.59,6.13)$ & & $(0.05,0.15)$ & & $(20.46,115.25$ & & \\
\hline \multirow[t]{2}{*}{9} & 200 & 0.78 & 0.96 & 18.16 & C & 0.23 & W & 79.38 & 29.51 & $<0.001$ \\
\hline & & $\begin{array}{l}(0.66- \\
0.87)\end{array}$ & $\begin{array}{l}(0.78- \\
0.99)\end{array}$ & $(3.03,109.06)$ & & $(0.14,0.37)$ & & $(10.20,617.92)$ & & \\
\hline \multirow[t]{2}{*}{8} & 300 & 0.77 & 0.97 & 26.40 & C & 0.24 & W & 112.02 & 23.15 & $<0.001$ \\
\hline & & $(0.64,0.87)$ & $(0.81,1.00)$ & $(3.42,203.67)$ & & $(0.14,0.40)$ & & $(11.57,1084.22)$ & & \\
\hline \multirow[t]{2}{*}{9} & 400 & 0.66 & 0.98 & 31.80 & C & 0.35 & W & 91.42 & 33.64 & $<0.001$ \\
\hline & & $(0.52,0.78)$ & $(0.86,1.00)$ & $(4.42,228.74)$ & & $(0.24,0.51)$ & & $(12.22,683.71$ & & \\
\hline \multirow[t]{2}{*}{12} & 500 & 0.59 & 0.96 & 14.87 & $\mathrm{C}$ & 0.43 & W & 34.63 & 25.94 & $<0.001$ \\
\hline & & $(0.49,0.68)$ & $(0.89,0.99)$ & $(5.16,42.86)$ & & $(0.34,0.56)$ & & $(11.12,107.89)$ & & \\
\hline \multicolumn{11}{|c|}{ HIV-negative PJP patients VS controls subgroup } \\
\hline \multirow[t]{2}{*}{5} & 80 & 0.87 & 0.68 & 2.74 & W & 0.19 & $S$ & 14.05 & 0.46 & 0.397 \\
\hline & & $(0.64,0.96)$ & $(0.35,0.89)$ & $(0.94,8.02)$ & & $(0.04,0.86)$ & & $(1.15,171.50)$ & & \\
\hline \multirow[t]{2}{*}{5} & 200 & 0.66 & 0.97 & 20.01 & $\mathrm{C}$ & 0.36 & W & 56.22 & 12.01 & 0.001 \\
\hline & & $(0.47,0.80)$ & $(0.48,1.00)$ & $(0.56,693.98)$ & & $(0.20,0.64)$ & & $(0.97,3256.48)$ & & \\
\hline \multirow[t]{2}{*}{5} & 300 & 0.66 & 0.97 & 21.66 & $\mathrm{C}$ & 0.35 & W & 61.97 & 9.50 & 0.004 \\
\hline & & $(0.40,0.85)$ & $(0.52,1.00)$ & $(0.75,624.22)$ & & $(0.17,0.72)$ & & $(1.47,2607.20)$ & & \\
\hline \multirow[t]{2}{*}{5} & 400 & 0.59 & 0.96 & 15.96 & C & 0.43 & W & 37.38 & 13.61 & 0.001 \\
\hline & & $(0.38,0.77)$ & $(0.68,1.00)$ & $(1.44,176.64)$ & & $(0.26,0.70)$ & & $(2.88,484.83)$ & & \\
\hline \multirow[t]{2}{*}{5} & 500 & 0.57 & 0.99 & 54.15 & C & 0.44 & W & 123.60 & 22.69 & $<0.001$ \\
\hline & & $(0.37,0.75)$ & $(0.60,1.00)$ & $(1.03,2840.30)$ & & $(0.28,0.68)$ & & $(2.60,5881.55)$ & & \\
\hline \multicolumn{11}{|c|}{ HIV-positive PJP patients VS controls subgroup } \\
\hline \multirow[t]{2}{*}{7} & 80 & 0.94 & 0.71 & 3.20 & W & 0.09 & $\mathrm{C}$ & 37.35 & 5.57 & 0.031 \\
\hline & & $(0.90,0.96)$ & $(0.49,0.86)$ & $(1.65,6.21)$ & & $(0.05,0.15)$ & & $(12.66,110.15)$ & & \\
\hline \multirow[t]{2}{*}{5} & 200 & 0.93 & 0.96 & 22.79 & $\mathrm{C}$ & 0.07 & C & 324.43 & 3.54 & 0.085 \\
\hline & & $(0.72,0.99)$ & $(0.47,1.00)$ & $(0.92,562.20)$ & & $(0.01,0.36)$ & & $(3.52,29910.97)$ & & \\
\hline \multirow[t]{2}{*}{4} & 300 & 0.87 & 0.98 & 38.44 & $\mathrm{C}$ & 0.13 & $S$ & 292.10 & 4.95 & 0.042 \\
\hline & & $(0.62,0.97)$ & $(0.38,1.00)$ & $(0.55,2701.76)$ & & $(0.04,0.48)$ & & $(1.74,48957.10)$ & & \\
\hline \multirow[t]{2}{*}{6} & 400 & 0.74 & 0.98 & 30.39 & $\mathrm{C}$ & 0.27 & W & 112.36 & 22.06 & $<0.001$ \\
\hline & & $(0.51,0.88)$ & $(0.74,1.00)$ & $(2.31,399.53)$ & & $(0.13,0.55)$ & & $(7.31,1726.67)$ & & \\
\hline \multirow[t]{2}{*}{6} & 500 & 0.70 & 0.94 & 12.63 & $\mathrm{C}$ & 0.32 & W & 40.01 & 0.146 & 0.023 \\
\hline & & $(0.51,0.84)$ & $(0.75,0.99)$ & $(2.13,74.97)$ & & $(0.17,0.60)$ & & $(4.01,390.49)$ & & \\
\hline \multicolumn{11}{|c|}{ PJP VS Colonized patients subgroup } \\
\hline \multirow[t]{2}{*}{6} & 80 & 0.86 & 0.82 & 4.70 & W & 0.17 & S & 26.90 & 3.367 & 0.093 \\
\hline & & $(0.73,0.93)$ & $(0.73,0.88)$ & $(3.11,7.08)$ & & $(0.09,0.34)$ & & $(11.17,64.81)$ & & \\
\hline \multirow[t]{2}{*}{6} & 200 & 0.69 & 1.00 & 168.11 & $\mathrm{C}$ & 0.32 & W & 532.87 & 2.139 & 0.172 \\
\hline & & $(0.60,0.76)$ & $(0.72,1.00)$ & $(1.73,16099.44)$ & & $(0.24,0.41)$ & & $(4.96,57244.18)$ & & \\
\hline \multirow[t]{2}{*}{5} & 300 & 0.64 & 1.00 & 130.58 & $\mathrm{C}$ & 0.36 & W & 361.28 & 0.687 & 0.355 \\
\hline & & $(0.52,0.75)$ & $(0.64,1.00)$ & $(1.08,15838.72)$ & & $(0.26,0.51)$ & & $(2.54,51376.9)$ & & \\
\hline
\end{tabular}




\begin{tabular}{|c|c|c|c|c|c|c|c|c|c|}
\hline 5 & 400 & $\begin{array}{l}0.54 \\
(0.48,0.60)\end{array}$ & $\begin{array}{l}1.00 \\
(1.00,1.00)\end{array}$ & $\mathrm{NC}$ & $\begin{array}{l}0.46 \\
(0.40,0.53)\end{array}$ & W & NC & NC & NC \\
\hline 6 & 500 & $\begin{array}{l}0.47 \\
(0.41,0.54)\end{array}$ & $\begin{array}{l}1.00 \\
(1.00,1.00)\end{array}$ & NC & $\begin{array}{l}0.54 \\
(0.48,0.61)\end{array}$ & $\mathrm{N}$ & NC & $\mathrm{NC}$ & NC \\
\hline
\end{tabular}

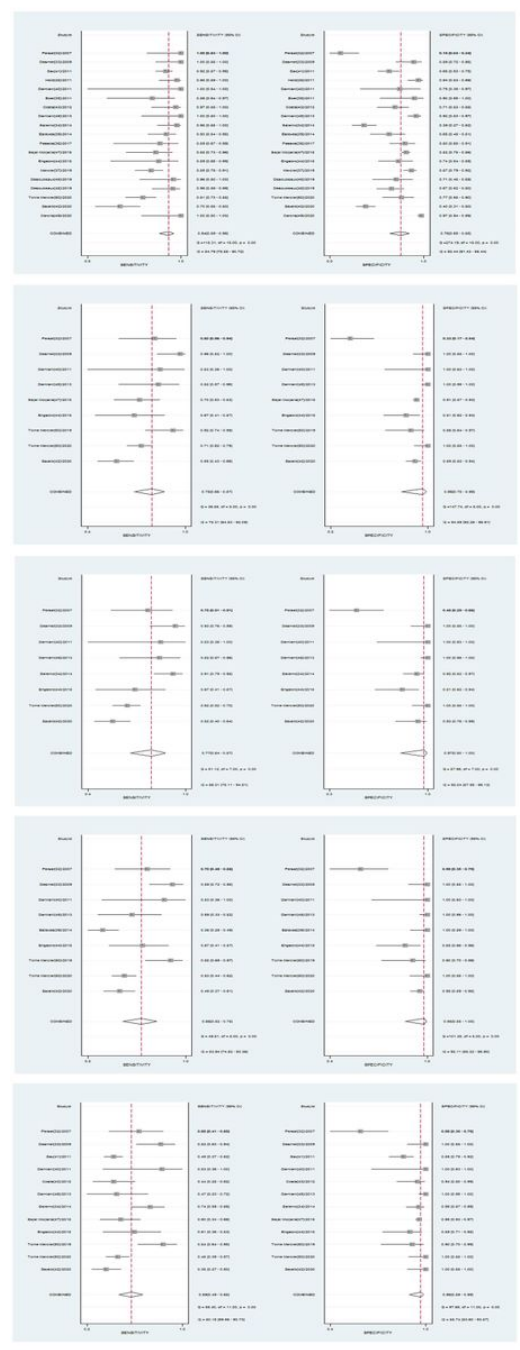

Figure 2

a Forest plot of sensitivity and specificity for the diagnosis of Pneumocystis jirovecii pneumonia (PJP patients vs controls) at the cutoff values of serum BDG $80 \mathrm{pg} / \mathrm{mL}$. Circles in the squares represent the point estimate of each study, while the horizontal line represents the $95 \% \mathrm{Cl}$. The dashed vertical line represents the average point estimate and the diamond shape represents the $95 \% \mathrm{Cl}$ of the average estimate. b Forest plot of sensitivity and specificity for the diagnosis of Pneumocystis jirovecii pneumonia (PJP patients vs controls) at the cutoff values of serum BDG 200pg/mL. Circles in the squares represent the point estimate of each study, while the horizontal line represents the $95 \% \mathrm{Cl}$. The dashed vertical line represents the average point estimate and the diamond shape represents the $95 \% \mathrm{Cl}$ of the average estimate. c Forest plot of sensitivity and specificity for the diagnosis of Pneumocystis jirovecii pneumonia (PJP patients vs controls) at the cutoff values of serum BDG 300pg/mL. Circles in the squares represent the point estimate of each study, while the horizontal line represents the $95 \% \mathrm{Cl}$. The dashed vertical line represents the average point estimate and the diamond shape represents the $95 \% \mathrm{Cl}$ of the average estimate. $\mathrm{d}$ Forest plot of sensitivity and specificity for the diagnosis of Pneumocystis jirovecii pneumonia (PJP patients vs controls) at the cutoff values of serum BDG $400 \mathrm{pg} / \mathrm{mL}$. Circles in the squares represent the point estimate of each study, while the horizontal line represents the $95 \% \mathrm{Cl}$. The dashed vertical line represents the average point estimate and the diamond shape represents the $95 \% \mathrm{Cl}$ of the average estimate. e Forest plot of sensitivity and specificity for the diagnosis of Pneumocystis jirovecii pneumonia (PJP patients vs controls) at the cutoff values of serum BDG 500pg/mL. Circles in the squares represent the point estimate of each study, while the horizontal line represents the $95 \% \mathrm{Cl}$. The dashed vertical line represents the average point estimate and the diamond shape represents the $95 \% \mathrm{Cl}$ of the average estimate. 


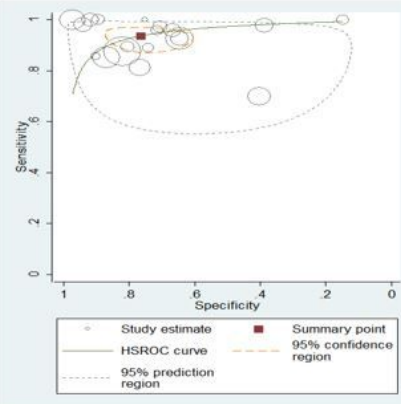

A, cutoff value of serum BDG $80 \mathrm{pg} / \mathrm{mL}$.

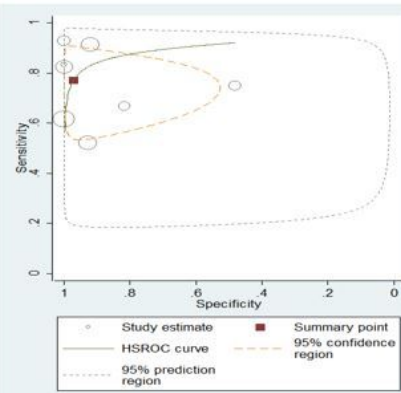

C, cutoff value of serum BDG $300 \mathrm{pg} / \mathrm{mL}$.

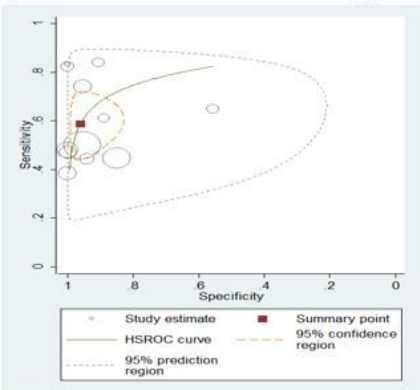

E, cutoff value of serum BDG $500 \mathrm{pg} / \mathrm{mL}$.

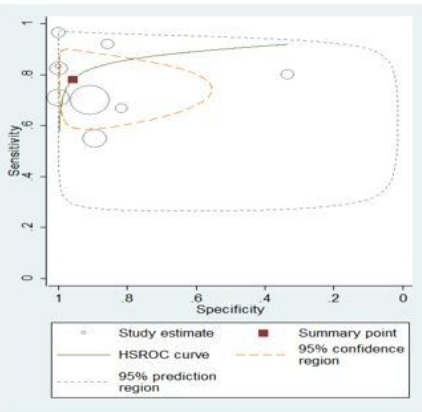

B, cutoff value of serum BDG $200 \mathrm{pg} / \mathrm{mL}$.

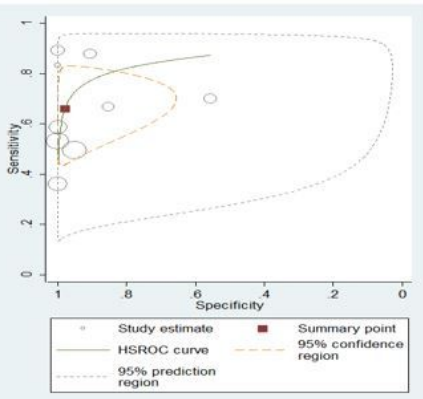

D, cutoff value of serum BDG $400 \mathrm{pg} / \mathrm{mL}$.

\section{Figure 3}

Pooled point estimates with $95 \%$ confidence regions of sensitivity/specificity and the hierarchical summary receiver-operating characteristic(HSROC) curve for the different cutoff values of BDG in PJP patients vs controls group. 